\title{
Experimental Use of Remote Sensing by Private Range Managers and Its Influence on Management Decisions
}

\author{
H. Scott Butterfield ${ }^{1}$ and Carolyn M. Malmstrom ${ }^{2}$ \\ Authors are ${ }^{1}$ Ecoregional Ecologist, The Nature Conservancy, San Luis Obispo, CA 93401; and ${ }^{2}$ Assistant Professor, \\ Department of Plant Biology, Michigan State University, East Lansing, MI 48824.
}

\begin{abstract}
Although remote sensing has many potential applications for range management, its use by range managers thus far has been limited. To investigate the factors that encourage use of remote sensing and to examine its influence on decision making by individuals who manage privately owned rangeland, we evaluated the decision-making processes of 3 ranch owners and 1 professional ranch manager who were introduced to remote sensing while collaborating with us in a rangeland stewardship program in California. Two of the participants had extensive ranching experience (11 to $>20$ years) and managed large cattle ranches $(1000$ to $>2000 \mathrm{ha})$, and 2 had less experience and managed smaller sheep ranches $(<200$ ha). During the 5 -year program, the participants implemented a series of new management practices, including prescribed burning, rotational grazing, and seeding of native grasses, with the aim of reducing noxious weeds and increasing productivity. We used remote sensing to quantify the effect of these practices and provided ranch-wide remote sensing analyses to each manager on a password-protected Web site. Using case study methodologies, we found that managers of larger, commercially active ranches found the experimental use of remote sensing to be a highly positive experience that convinced them that this technology could help address difficult management situations and increase ranch profitability. This suggests that the broad use of remote sensing by managers of privately held, commercial rangelands may be limited in part by the simple lack of opportunity to test these technologies. Programs that assist ranchers in obtaining appropriate remote sensing products thus may be a cost-effective way to enhance conservation on private rangelands. Our findings suggest that voluntary self-analysis by ranchers of the landscape dynamics of their own properties is likely to lead to more engaged conservation efforts than will topdown prescriptions.
\end{abstract}

\section{Resumen}

Aun cuando el potencial de sensores remotos en manejo de pastizales es alto, su uso en situaciones practicas limitada. El objetivo de este estudio fue evaluar los factores que motivan la utilización de sensores remotos y su influencia en el proceso de toma de decisiones en ranchos privados. Se evaluó el proceso de toma de decisiones de 3 propietarios de ranchos y 1 administrador profesional quienes fueron capacitados en el uso de sensores remotos durante su colaboración en un programa de conservación de recursos en California. Dos de los participantes contaban con un extensa experiencia en el manejo de rancho (de 11 a 20 años) y manejaban ranchos grandes (1000 a 2000 ha) y los otros 2 participantes tenían menos experiencia y manejaban ranchos mas pequeños para producción de borrego $(<200)$. Durante los 5 años del proyecto, los participantes implementaron una serie de nuevas practicas de manejo, incluyendo quemas prescritas, pastoreo rotacional, y resiembra de pastos nativos con el propósito de reducir la presencia de plantas indeseables e incrementar la productividad. Los sensores remotos se utilizaron para cuantificar el efecto de estas prácticas y proveer a los participantes la información a través de un sitio web protegido del un análisis integral del rancho utilizando sensores remotos. Los participantes de los ranchos grandes con mayor actividad comercial encontraron el uso de sensores remotos como una experiencia altamente positiva y se mostraron convencidos de que esta tecnología puede ser de mucha utilidad para manejar situaciones difíciles e incrementar las utilidades del rancho. Estos resultados indican que el uso limitado de sensores remotos en pastizales de ranchos privados puede deberse en parte a la falta de oportunidad para probar estas tecnologías. Se requieren programas que permitan ayudar a los propietarios y administradores de ranchos a obtener los sensores remotos apropiados para garantizar un costo retorno efectivo del uso de estos equipos para beneficiar la conservación de los pastizales en estas áreas. Estos resultados sugieren que un autoanálisis voluntario por parte de los propietarios de ranchos sobre la dinámica del paisaje de sus propiedades puede inducir a la realización de esfuerzos de conservación mas agresivos que las recomendaciones que se pudieran obtener de otros medios.

Key Words: case study analysis, collaboration, conservation, invasive species, noxious weeds, ranching

Research was funded by CalFed Bay-Delta Authority Grant 2001-H211-01-N31 to C.M.M. and by the Michigan Agricultural Experiment Station.

At the time of research, Butterfield was a graduate research assistant, Dept of Plant Biology, Michigan State University, East Lansing, MI.

Correspondence: H. Scott Butterfield, The Nature Conservancy, 75 Higuera St., Suite

200, San Luis Obispo, CA 93401. Email: scott_butterfield@tnc.org

Manuscript received 28 October 2005; manuscript accepted 11 May 2006.

\section{INTRODUCTION}

Few range managers currently use remote sensing products to inform their management decisions (Daberkow and McBride 2000; Hunt et al. 2003; Washington-Allen et al. 2006), even though remote sensing offers valuable means of assessing the 
Table 1. Motivation for involvement in the stewardship program. Responses were given in survey 1 , before managers were provided access to the remote sensing products, on a Likert scale $(1=$ no motivation to $5=$ high motivation).

\begin{tabular}{lcccc}
\hline & Cattle 1 & Cattle 2 & Sheep 1 & Sheep 2 \\
\hline Increasing forage production & 5 & 5 & 5 & 1 \\
Decreasing noxious weeds & 4 & 3 & 5 & 3 \\
Establishing native bunchgrasses & 5 & 1 & 2 & 1 \\
Promoting landowner outreach & 4 & 2 & 4 & 5 \\
Increasing water quality & 5 & 2 & 1 & 1 \\
\hline
\end{tabular}

influence of management practices on forage production (e.g., Pickup et al. 1994) and invasive noxious weed spread (e.g., Lass et al. 1996) across large range units. Several studies have examined factors influencing the use of innovative technologies in general (Fliegel 1993; Rogers 1995; Röling and Wagemakers 1998; Daberkow and McBride 2003) and of specific range management technologies, such as cattle vaccines (Harris et al. 1995) and prescribed burning (Kreuter et al. 2001). To our knowledge, however, no study has sought to identify factors that promote the use of remote sensing technologies by range managers or investigated how the use of remote sensing can influence manager decision making. With other innovative technology, low use rates have often been found to indicate either that the technology has not been successfully introduced to the end user (in this case, the range manager) or that the end user does not see its utility (Fliegel 1993; Kreuter et al. 2001; Daberkow and McBride 2003). In the case of remote sensing, use also may be limited by its cost and complexity or by the lack of opportunity to try it.

California's rangelands are a good example of a system in which broad use of remote sensing technologies could benefit range managers by allowing them to assess management techniques for weed control and forage improvement over large areas. Since first settled by European immigrants, California's rangelands have been under pressure from human activities, which have resulted in the conversion of this system from one dominated by native vegetation including annual forbs and perennial bunchgrasses to one dominated by introduced annual grasses (Heady 1977; D'Antonio and Vitousek 1992). These introduced annual grasses, which have relatively high forage value, have supported an extensive ranching economy in the state for more than 150 years (George and Fulgham 1989). Today, however, a wave of introduced noxious species, including yellow starthistle (Centaurea solstitialis L.; all nomenclature follows Hickman 1993), medusahead (Taeniatherum caput-medusae [L.] Nevski), and barbed goatgrass (Aegilops triuncialis L.), are spreading through the region, reducing rangeland productivity and threatening the economic sustainability of established ranches (Maddox and Mayfield 1985; Young 1992; Peters et al. 1996). Unlike the previously established exotic species, these new invaders provide poor forage during most of the season (Bovey et al. 1961; Lusk et al. 1961; Callihan et al. 1982, 1995; Peters et al. 1996). To manage the noxious weeds, range managers are testing a variety of new management approaches, but it can be costly for them to assess the consequences of the new approaches with on-
Table 2. Management practices tested during the stewardship program.

\begin{tabular}{|c|c|}
\hline Manager & Practice \\
\hline \multicolumn{2}{|l|}{ Cattle 1} \\
\hline 1 unit totaling 12.1 ha & $\begin{array}{l}\text { Prescribed burning, seeding of native } \\
\text { bunchgrasses, rotational grazing }\end{array}$ \\
\hline 2 units totaling 157.8 ha & Prescribed burning, rotational grazing \\
\hline 6 units totaling 157.8 ha & Rotational grazing \\
\hline 1 unit totaling 1011.7 ha & Fencing planned \\
\hline \multicolumn{2}{|l|}{ Cattle 2} \\
\hline 1 unit totaling 16.2 ha & Rotational grazing (spring only) \\
\hline 6 units totaling 550.4 ha & Rotational grazing (fall only) \\
\hline 1 unit totaling 26.3 ha & $\begin{array}{l}\text { Prescribed burning, seeding of native } \\
\text { bunchgrasses }\end{array}$ \\
\hline \multicolumn{2}{|l|}{ Sheep 1} \\
\hline 1 unit totaling 24.3 ha & $\begin{array}{l}\text { Rotational grazing, prescribed burning } \\
\text { seeding of clover }\end{array}$ \\
\hline 3 units totaling 97.1 ha & $\begin{array}{l}\text { Prescribed burning, seeding of native } \\
\text { bunchgrasses, rotational grazing }\end{array}$ \\
\hline 2 units totaling 46.5 ha & Prescribed burning, rotational grazing \\
\hline \multicolumn{2}{|l|}{ Sheep 2} \\
\hline 1 unit totaling 16.2 ha & $\begin{array}{l}\text { Prescribed burning, seeding of native } \\
\text { bunchgrasses, rotational grazing }\end{array}$ \\
\hline 1 unit totaling 16.2 ha & Rotational grazing \\
\hline
\end{tabular}

the-ground surveys alone, given the extent of their properties. Remote sensing offers an opportunity for managers to evaluate large areas more quickly and cost-effectively.

To identify factors that promote the use of remote sensing by range managers and to investigate the influence of remote sensing on range management decisions, we used an in-depth, case study approach to examine the experimental use of remote sensing products by 4 individuals who manage private rangelands in the western Sacramento Valley foothills in California, as part of a 5-year (1999-2004) rangeland stewardship program (Malmstrom et al. 2004). Managers were involved in the program primarily because they wanted to increase the productivity of their land and decrease noxious weed levels (Table 1). To do this, they tested a series of new management practices (Table 2). None of these managers had specifically used remote sensing data to make management decisions on his or her property prior to involvement in our study.

Here we examine 1) the ways in which managers' ranching approaches and previous ranching experiences influenced their interest in and use of our experimental remote sensing products and 2) the ways in which the remote sensing products in turn influenced the managers' decision making. We produced a broad suite of remote sensing products, which included a time series of spring forage estimates for the watershed and a map of noxious weed distributions. This information was presented to the managers through an interactive Web site that allowed each to view his or her property as a whole or on a field-by-field basis. Data were presented in graphs and as maps, which could be selected to show estimated values for a given time period or patterns of change across years. We conducted surveys and interviews with all 4 managers before and after they worked 
with these remote sensing materials and then used case study methodologies to analyze their responses.

\section{METHODS}

\section{Growing Season Terminology}

Most California rangelands experience a Mediterranean climate, distinguished by a moderate fall-winter-spring growing season and a prolonged summer drought. We thus consider time in terms of "biological" years that begin in fall at the end of the summer drought (i.e., September 200N) and continue into August of the following calendar year $(200 \mathrm{~N}+1)$. We refer to September-November as fall, December-February as winter, March-May as spring, and June-August as summer. For most annual range grasses, the growing season begins in fall with the first rains, continues through the wet winter, and reaches its peak in spring. By late May, most annual range grasses are senesced, but the newer noxious weeds may remain green later into the summer.

\section{Remote Sensing Products}

To produce maps of green spring forage values, we used fieldcalibrated algorithms to estimate green forage biomass from NDVI (normalized difference vegetation index) values derived from Landsat satellite imagery acquired in late March or early April of each year from 1999 to 2004 (Malmstrom et al. 2004). We used Landsat imagery because of its availability and cost effectiveness to private range managers as well as the appropriateness of its spatial scale $(30 \mathrm{~m})$ for rangeland forage analyses. Forage estimates were made only at the peak of the growing season when green biomass was dominant, because we found that remote sensing algorithms for quantifying senescent biomass previously developed for Southwestern systems (Qi et al. 2000) failed to perform adequately in the California annual grasslands (Malmstrom et al. 2004). To map the distribution of 2 dominant noxious weeds-medusahead and goatgrass-we used a time series of fine spatial resolution ( 1 foot) aerial photography acquired at key phenological time points when these weeds showed reflectance patterns distinct from the more valuable forage grasses (Malmstrom et al. 2004). To provide managers interactive access to the remote sensing products, we built a password-protected Web site on which each manager had access to information about only his or her own property. The Web site offered managers wholeproperty and field-by-field access to spring forage maps from 1999 to 2004, forage change maps comparing differences across years, a quantitative 5 -year forage analysis, a map of noxious weed distribution in 2004, and land use history and weather data.

\section{Surveys and Interviews of Land Managers}

To gather baseline information about the managers' experiences, practices, and attitudes, we asked each manager to complete a survey in March 2004, prior to introducing him or her to the remote sensing materials. This survey contained 25 multiple-choice Likert-scale questions (Miles and Huberman 1994; Strauss and Corbin 1998) and 10 short-answer ones. Among the subjects we explored were the managers' 1) as- sessment of the current range conditions at their property and the need for new management approaches and 2) previous experiences with using new management practices, such as prescribed burning for weed control. We interviewed each manager individually to clarify his or her responses and to gather additional information about management approaches used on his or her property and its land use history.

We then showed all 4 managers how to use the project Web site to access the remote sensing products and gave them 5 months (March-August 2004) in which to explore the products and test their utility for management decision making. In August we resurveyed and interviewed the managers to determine to what extent they had used the remote sensing products, how the products had influenced their decision making, and what improvements might increase their interest in using remote sensing in the future. Like the first survey, the second one contained 25 multiple-choice Likert-scale and 10 short-answer questions, about half of which were identical to those asked in the first survey. Both surveys adhered to Dillman's (1978) guidelines, except that we did not use follow-up mailings because our group was small enough to contact by phone.

\section{Analysis of Responses}

Because our study group was by necessity small, we used case study methodologies to analyze manager responses (Yin 2003). Case studies provide the opportunity to examine intensively the experiences and responses of a smaller group of managers, who represent elements of a larger management community. Although case studies provide substantial insight into manager motivation, care must be taken when extrapolating results from individual case studies to other situations. To construct the case studies, we first coded the survey and interview data to identify manager responses in 2 broad categories of interest (Miles and Huberman 1994; Strauss and Corbin 1998): 1) Manager characteristics and experience and 2) influence of remote sensing on management decisions. Manager characteristics and experience included descriptive information about each manager and his or her management operations; influence of remote sensing on management decisions included information about how each manager used remote sensing data to evaluate his or her success in meeting his or her own management objectives. During the coding process we sought illuminating quotations from each manager that provided insight into his or her own unique story.

We used the managers' responses from the second set of surveys and interviews to determine their response to the remote sensing products. We defined the use of remote sensing during the study as the extent to which managers accessed the Web site and our remote sensing products with the purpose of using the products to evaluate the impact of their management efforts and to decide which approaches to use in the future. We also quantified the managers' self-reported planned intent to use these same remote sensing products for management evaluations in the future and to invest in new remote sensing data and products for their properties.

\section{RESULTS}

We present each case study individually, with 2 sections within each: 1) Manager characteristics and experience, which dis- 
cusses the characteristics of each manager and his or her management operations and motivations for involvement in the stewardship program, and 2) influence of remote sensing on management decisions, which discusses how each manager used the experimental remote sensing products to evaluate his or her management strategies as well as his or her suggestions about how the products could be improved to enhance their value for private range managers such as themselves or for long-term management planning. To protect their privacy, the managers and case studies are referred to by code names: Cattle 1, Cattle 2, Sheep 1, and Sheep 2.

\section{Cattle 1}

Manager Characteristics and Experience. At approximately 2000 ha, Cattle 1 was the largest ranch studied. Cattle 1 has been family-owned for over 20 years and has been used primarily for commercial cattle grazing during that time. The landowners' motivations for involvement in the stewardship program were diverse but centered on the desire to increase ranch productivity (Table 1). Both the current and former managers (son and father) agreed that it was important to increase the value of their land, especially given pressure from urbanization, governmental regulations, and global competition, so that their family business "makes it to the next generation." The father believed "grazing alone maintained feed for cattle" and that "burning and seeding native perennials was too expensive" to be a property-wide solution. However, his son believed that to "preserve the ranching way of life in California" it was necessary to implement management strategies that took advantage of new technologies and cooperative partnerships. His outlook was evident in the diversity of management practices implemented during the program (Table 2). Rotational grazing, the practice of alternating periods of grazing and rest among 2 or more fenced pastures throughout the season, was an especially distinctive change that occurred in the last 1-2 years of the program because the ranch previously had used set stocking rates. Cattle 1's manager believed that "decreasing stocking rates in the spring would allow more regrowth and, combined with burning in the summer, would have a positive effect on forage."

Influence of Remote Sensing on Management Decisions. Before working with the remote sensing products, Cattle 1's manager believed that there was a "place for remote sensing in ranching" but emphasized that it could never replace the skills of a rancher. He believed that remote sensing would allow him to visualize forage and weed levels quickly across his entire property, which would allow him to compare fields enrolled in the program with those being managed with a traditional grazing approach.

After evaluating the remote sensing products on the project Web site, Cattle 1's manager concluded that he could use the weed map and the time series of forage estimates to determine whether the programs' restoration efforts had made impacts on weed control and forage production that were large enough to justify their continued use. During the second interview, for example, he discussed how his analysis of the remote sensing maps had led him to conclude that "while burning increased forage levels the year following the burn, 2 years later medusa was back, and forage levels were where they were before the burn." Therefore, "burning is only beneficial if used along with seeding of good competitors, such as native perennial grasses." He indicated that his evaluation also had led him to conclude that his rotational grazing efforts had increased forage and decreased weeds during the 20032004 growing season. This conclusion was significant in a management context because "managing with cattle requires fewer additional inputs of time and money compared to burning and seeding."

Based on the value he gained from the remote sensing products we produced for the lower portion of his ranch, Cattle 1 's manager requested that we also produce similar products for the ranch's upper portion. He found this upper 1000 -ha portion to be more difficult to manage because of its ruggedness, size, and lack of fencing, and so he had not yet tried restoration efforts in it (Table 2). The additional forage maps led Cattle 1's manager to conclude that forage increases in the closely managed lower portions of the property had been much greater than those in the upper portions. He believed that these differences were due to his inability to "control cattle and visually inspect" the upper portions of the property "throughout the season." He believed that remote sensing data would allow him to address both issues, and he planned to use the forage maps to coordinate fencing of the upper portion in 2004-2005 and to monitor forage thereafter (Table 2). His first-hand experience of remote sensing's capacity to quantify management effects and help enhance management efforts in remote terrain led Cattle 1's manager to increase the amount of money that he would be willing to invest annually in these technologies from approximately $\$ 100$ (survey 1) to $\$ 500$ (survey 2), with the latter value exceeding the cost of an entire Landsat Thematic Mapper (TM) scene (\$425).

The outreach efforts at Cattle 1 involved a 2 -way exchange of information between scientists and range managers. This exchange allowed us to produce remote sensing products customized for the experience level and management needs of Cattle 1's manager. Cattle 1's manager emphasized that the remote sensing did not change which management strategies he believed were possible, but rather the means by which he could assess their effectiveness: "This is what I meant when I said remote sensing was only a tool. It helps me see the effects of management, but it cannot do them for me." Voicing an important common theme among the case study group, he indicated that he believed that the increasing challenges of ranching were making cooperation between ranchers and scientists even more important. This program confirmed to him that such partnerships "improve the chances of rancher survival.”

\section{Cattle 2}

Manager Characteristics and Experience. At approximately 1200 ha, Cattle 2 was the second largest ranch in our sample. Cattle 2 is family-owned, commercially grazed by cattle, and managed by a professional range manager with over 20 years of ranching experience. Cattle 2's manager participated in the program to increase ranch productivity (Table 1). He felt rotational grazing was the best way to accomplish this 
because it "did not require an additional investment of time and money."

Influence of Remote Sensing on Management Decisions. Prior to evaluating the project's remote sensing products, Cattle 2's manager was receptive to incorporating remote sensing data into his management regime because he believed that there was a "pressing need to increase the productivity and profitability" of his ranch and that these tools would allow him to "directly meet these needs." Cattle 2's manager felt remote sensing would be useful for analyzing forage and weed levels before and after grazing events. He believed that if monthly forage maps were available, he could make grazing adjustments during the season, which would allow him to maximize the time his cattle spent grazing while maintaining adequate forage for the following season. In addition, he thought that using the forage and weed maps together would allow him to determine whether there was "good feed in a field or just medusa."

After viewing the 2004 weed map, Cattle 2's manager was surprised to see high weed levels across select grazing fields. Even though he knew noxious weeds were a significant threat across his property, he believed that he had limited their impact with grazing alone. He concluded that weed increases were due not to the ineffectiveness of his grazing efforts, but rather to seasonal water limitations that restricted grazing to the spring when the weeds were maturing and thus unable to be grazed effectively by cattle. During the interview, he used the forage and weed maps together to show us that fields grazed only in the fall had both increased forage (Table 2) and decreased weed levels.

Even though Cattle 2's manager focused on grazing as a tool to manage his property, the size of the ranch prevented him from tracking these effects "across every field at the same time." After analyzing the time-series forage maps, he was encouraged by the capacity of remote sensing to allow him to track forage levels across different fields simultaneously without extensive field work and to easily compare values from growing seasons. Like Cattle 1's manager, Cattle 2's manager also believed that remote sensing data would allow him to manage more intensively the upper portions of his property, which would increase ranch productivity. Because of this potential, Cattle 2's manager increased the amount of money that he planned to invest annually in these technologies from approximately $\$ 0$ (survey 1) to $\$ 500$ (survey 2).

The collaborative nature of the landscape analysis effort motivated the managers of Cattle 1 and 2 to share their forage and weed species maps with one another, which allowed Cattle 2's manager to see the benefits of practices he did not implement during the program, such as the multiyear effect of burning and seeding with perennial grasses (Table 2). While the results did not substantially change his mind about which practices were most successful, they did convince him to try burning and seeding a 16 -ha field heavily infested with medusahead and under seasonal grazing restrictions (Table 2), beginning in 2005.

\section{Sheep 1}

Manager Characteristics and Experience. Sheep 1 was the largest sheep ranch in our sample, but at approximately 170 ha it was significantly smaller than both cattle ranches. The ranch was purchased by the current landowner in 1998 and subsequently grazed by about 200 ewes. This manager initially had little commercial ranching experience but is highly educated and made considerable efforts to increase her knowledge of ranching during the program by enlisting the help of range managers and scientists. In addition, because ranching is not her primary occupation, she has employed a professional range manager to assist her. In this study we interacted solely with the landowner-manager herself. Her motivations for involvement in the program were diverse, but she emphasized increasing ranch productivity and decreasing noxious weed levels (Table 1).

When purchased in 1998, Sheep 1 was dominated by medusahead and yellow starthistle. To restore it, half of the property was burned in the summer of 1999 and then seeded with native perennial bunchgrasses in the fall of 2000. Unfortunately, bunchgrass populations did not immediately take hold. During the 2000-2001 growing season, the landowner was thus forced to confine her sheep to the unburned portion of her property, which led to overgrazing. More fields were burned in 2002-2003, with varying degrees of success; the most success occurred in a 24-ha field where the landowner used intensive short-duration grazing followed by burning and seeding with clover (Table 2).

Influence of Remote Sensing on Management Decisions. Even before evaluating the remote sensing products, Sheep 1's manager felt that forage and weed maps would provide her with an essential overview of her ranch and a means to "determine which management practices worked and which fields needed to be attacked next." Because almost every hectare of Sheep 1 was involved in a restoration test, Sheep 1's manager had the unique opportunity to see the short- and long-term effects of a variety of management efforts in combination with rotational grazing practices (Table 2).

Before analyzing the remote sensing products, Sheep 1's manager did not believe prescribed burning was a long-term solution for her property because of its "cost, danger, and varied results." After the unsuccessful restoration efforts of 1999-2000, Sheep 1's landowner expected this portion of her property to have low forage levels and large areas of medusahead and goatgrass. The remote sensing products supported these beliefs and contributed to her conclusion that prescribed burns alone were not effective enough to offset their high cost. In addition, the time-series forage and weed maps led Sheep 1's manager to decide that rotational grazing in combination with other practices, such as sowing good weed competitors, was the most effective strategy for increasing forage and decreasing weeds on her property. Because remote sensing data allowed Sheep 1's manager to base her management efforts on multiyear forage trends, she increased the amount of money that she planned to invest annually in these technologies from approximately $\$ 100$ (survey 1 ) to $\$ 500$ (survey 2 ).

Sheep 1's manager believed that the outreach efforts were an important part of the stewardship program. She felt these efforts were a model for how programs should be carried out in the future and that "the in-person visits were essential components of establishing trust and sharing knowledge." Like other participants, she emphasized the value of collaborative research, and she indicated that she believed that "California 
farm land was being swallowed up by developers and that projects like this should serve as models for how scientists and landowners can work together."

\section{Sheep 2}

Manager Characteristics and Experience. At approximately 30 ha, Sheep 2 was the smallest ranch in this study. The managers have owned the ranch for approximately 20 years but have never commercially managed the forage on their property. Sheep 2's managers were involved in the stewardship program to increase collaborative interactions with scientists and other participating landowners and to help conserve the grassland habitat on their property (Table 1). Sheep 2's managers did not manage the forage or weed levels on their property during the program, but they did allow project scientists and other property owners to conduct restoration tests on their property (Table 2).

Influence of Remote Sensing on Management Decisions. After accessing the Web site, Sheep 2's managers responded that while the Web site "looked great," they had "no need for weed maps or analyses of management practices." They emphasized that if their property were larger the remote sensing products would be helpful, but because it was so small they could "walk across the property if they needed to see what was going on." Although Sheep 2's managers did not believe that the Web site was useful on their property, they did see the benefit of time-series forage and weed maps; they commented that "seeing how the land has changed allows us to see whether we are part of the problem or part of the solution."

\section{DISCUSSION}

\section{Factors Influencing the Use of Remote Sensing by Managers}

In this experimental test of the value of remote sensing for private ranch managers, we produced and offered, at no cost to the managers, a suite of remote sensing products tailored to the managers' needs and worked individually with each manager to ensure that any questions or concerns he or she had about how to access the products on the project Web site could be addressed promptly. In doing so, we thereby removed or reduced several barriers that might otherwise prevent private managers from experimenting with remote sensing as a management tool, such as its cost and potential uncertainty on the managers' part about how to get appropriate products for their properties. We then examined, among our case study group, what other factors influenced the degree to which each manager was willing to "use" the remote sensing products we provided, that is, to analyze and draw conclusions from the products about the success of their management strategies. In addition, we evaluated the influence of the experiment on the managers' self-reported willingness to purchase remote sensing products in the future.

In general, it has been found that several criteria need to be met for users to begin to use and invest in new technology. Rogers (1995) and Somers (1998) concluded, for example, that end users first must believe that there is a relative advantage (e.g., financial) to using the new technologies and then have the opportunity to determine how best to incorporate these technologies into their current practices. In our study the 3 managers whose properties are used for commercial livestock production (Cattle 1, Cattle 2, Sheep 1) spent the most time analyzing and evaluating the remote sensing data and were most interested in purchasing remote sensing products in the future. These 3 managers concluded that remote sensing provided tools that could help maximize their properties' productivity and that they would like to cooperatively purchase additional remote sensing products in the future. After experimenting with the remote sensing products, all 3 managers of commercially active properties increased the amount of money they indicated they would be willing to spend on remote sensing data. Individually, their planned annual investments of approximately $\$ 500$ would each be enough to purchase an entire single Landsat TM scene $(a 170 \times 183 \mathrm{~km}$ scene costs $\$ 425$ ). If pooled, their planned annual investments of approximately $\$ 1500$ would be large enough to purchase multiple TM scenes and additional Geographic Information Systems (GIS) data for their properties or additional aerial photographs for noxious weed mapping. Although our expectations of use and investment did not initially assume that cost sharing would be necessary, from this particular study we would conclude that at least in the early stages of use, collaborations between managers increase the likelihood of investment by decreasing the annual financial obligation to any one manager. Unlike the other managers, the managers of the smaller, commercially inactive property (Sheep 2) spent less time evaluating the remote sensing data and were uninterested in purchasing products in the future.

Consistent with Rogers' and Somers' findings, it was evident that the managers who used the remote sensing products most extensively during our study and who were interested in purchasing products in the future were those who believed that the remote sensing technologies could offer them management advantages. The managers of the 3 commercially active ranches believed that their current management efforts were not optimized and that there was thus a need for new management approaches on their properties. These managers had participated in the stewardship program to increase forage production and decrease invasive noxious weed levels across their properties (Table 1), and they were willing to test new management approaches to meet these goals (Table 2). In other situations Hanselka et al. (1990) and Kreuter et al. (2001) likewise found that managers were more likely to use and invest in new range management technologies if range conditions across their properties were poor. In contrast, the managers of Sheep 2, while impressed by the remote sensing products, did not see a need to test new management approaches and thus were less interested in exploring the utility of remote sensing.

The managers most interested in using the remote sensing products not only felt that there was a need to try new management approaches but also believed that using remote sensing could effectively help them do it. Likewise, Kreuter et al. (2001) concluded that "Brush Busters" management approaches were broadly used and invested in across Texas rangelands because of their perceived effectiveness in decreasing brush and increasing productivity. During our study the managers of Cattle 1, Cattle 2, and Sheep 1 each had at least 
one experience that convinced them that they could increase the productivity and profitability of their property by using these particular remote sensing products to inform their management decisions. For example, the managers of Cattle 1 and 2 concluded that forage and weed species maps provided them with the opportunity to monitor their rotational grazing efforts more intensively during the season, which allowed them to maximize the time cattle spent grazing while making sure adequate forage was left for the following season. In addition, they were convinced that remote sensing approaches would allow them to extend their rotational grazing efforts to the upper portions of their properties, where increases in forage had been much smaller than in their more intensively managed lower portions. Sheep 1's manager recently had implemented a series of strategies aimed at increasing forage production and decreasing weed levels (Tables 1 and 2). She was able to use the multiyear forage analyses to determine the effectiveness of these efforts and to develop a comprehensive adaptive management strategy for her property. In contrast, the managers of Sheep 2 did not see the need to explore whether remote sensing could help increase ranch productivity or profitability because their ranch was not commercially active.

\section{Influence of Remote Sensing on Decision Making}

Range managers are skilled in reading and assessing landscapes and maps, and our case study group readily transferred these skills to interpreting remote sensing data and incorporating it in to their management analyses. Among our manager group, those managing commercially active properties believed that remote sensing data allowed them to base their decisionmaking processes on multiyear forage trends across their entire properties, rather than on 1-year forage changes across individual pastures. The ability to view multiyear forage trends allowed those managers who were actively managing their land to assess quantitatively the forage impact of new management practices they tested during the stewardship program and to determine whether these practices were short-term fixes or long-term solutions to problems such as increasing noxious weed levels. For example, the multiyear analyses enabled the managers of both Cattle 1 and Sheep 1 to conclude that they would invest in prescribed burning in the future only if it was done in coordination with seeding of good competitive forage grasses like native bunchgrasses or clovers; otherwise, they felt that the positive impact of fire on noxious weeds was too shortterm (1-2 years) for commercial range management operations to justify its expense and potential hazard.

The remote sensing products used in this study were developed with the input of our manager group. Mutual discussion of the remote sensing products during the program helped us tailor the Web site and forage maps to the needs and experiences of each manager and provided a forum in which to elicit information from managers about historical land use and past management strategies. Historical land use data are an invaluable resource for managers seeking to assess the longterm influence of management strategies and other factors such as invasive species and climate change. However, on many private ranches, including well-managed ones, data on stocking rates and other land use information are often not kept in a detailed or consistent manner. Through involvement in this study, our manager group was able to determine for themselves the value of coordinating remote sensing analyses with on-theground management data and, as a result, expressed increased commitment to keeping more detailed management (e.g., grazing) records for decision making in the future.

An important theme expressed throughout by the manager case study group was the importance of collaboration, among ranchers and between ranchers and scientists, in finding ways to optimize rangeland management in regions facing pressure from forces such as urbanization and invasive species. This sentiment contrasts with historical expressions of enmity between conservation biologists and Western ranchers (e.g., Jensen 2001) and indicates the overwhelming need for innovation to protect remaining rangelands as conservation and cultural resources (e.g., Weiss 1999). Our findings suggest that voluntary engagement in collaborative rangeland analyses not only can increase the success of stewardship programs like this one but is also more likely to be effective than top-down prescriptions in supporting long-term efforts to improve rangeland conditions. Our work demonstrates that such collaborations can foster the development and application of innovative management technologies and thereby facilitate efforts to enhance rangeland sustainability.

\section{MANAGEMENT IMPLICATIONS}

Our findings suggest that one hurdle impeding the broad use of remote sensing by managers of privately held, commercial rangelands may simply be the lack of opportunity to test it. When given this opportunity, all of the commercially active managers in our case study group responded very positively and found creative ways to use it effectively to evaluate their management efforts. These managers chose to use our remote sensing products during the study and indicated they intended to use them and buy more products in the future because the experimental tests convinced them that such remote sensing products would help optimize their management practices and increase ranch productivity and profitability.

Although the cost of some remote sensing products can be high, relatively low-cost data traditionally have been available to the public through well-established programs such as the Landsat data acquisition program. When such imagery are available, use of remote sensing by private range managers can be economically feasible, particularly if consortia of managers with properties falling within the same satellite scenes can collaboratively cost-share and obtain technical support from local universities or agencies. We hope that these findings will encourage more private range managers and scientists to collaborate on efforts to incorporate remote sensing into commercial range management and rangeland restoration efforts. Continued support of regular image acquisition by reliable, appropriate-scale satellite systems with public data availability is essential to this aim.

\section{ACKNOWLEDGMENTS}

We greatly appreciate the cooperation of all of the participating landowners and range managers, as well as J. Wirka, J. Boshoven, C. Rose, and 
V. Russell of Audubon-California. We thank A. Austin, D. Ebert-May, and P. Farrell for their help in developing the survey and interview protocols and A. Austin, M. Brunson, D. Ebert-May, V. Eviner, P. Farrell, F. Knapczyk, L. Lauerman, C. Vaughn, and 2 anonymous reviewers who provided invaluable comments on the manuscript.

\section{LITERATURE CITED}

Bovey, R. W., D. Le Tourneau, and L. C. Erickson. 1961. The chemical composition of medusahead and downy brome. Weeds 9:307-311.

Callihan, R. H., L. W. Lass, C. W. Hunt, and G. Pritchard. 1995. Comparative digestibility of yellow starthistle (Centaurea solstitialis L.). Moscow, ID: Western Society of Weed Science. Research Progress Report. 36 p.

Callihan, R. H., R. L. Sheley, and D. C. Thill. 1982. Yellow starthistle: identification and control. Moscow, ID: University of Idaho, College of Agriculture. Current Information Series No. 634. 4 p.

Daberkow, S. G., and W. D. McBride. 2000. Adoption of precision agriculture technologies by U.S. farmers. In: P. C. Robert, R. H. Rust, and W. E. Larson [EDS.]. Proceedings of the 5th International Conference on Precision Agriculture [CD-ROM]. Madison, WI: America Society of Agronomy.

Daberkow, S. G., and W. D. McBride. 2003. Farm and operator characteristics affecting the awareness and adoption of precision agriculture technologies in the US. Precision Agriculture 4:163-177.

D'Antonio, C. M., And P. M. Vitousek. 1992. Biological invasions by exotic grasses, the grass/fire cycle, and global change. Annual Review of Ecology and Systematics 23:63-87.

Dillman, D. A. 1978. Mail and telephone surveys: The total design method. New York, NY: John Wiley \& Sons. 375 p.

Fliegel, F. C. 1993. Diffusion research in rural sociology. Westport, CT: Greenwood Press. $138 \mathrm{p}$.

George, M. R., and K. O. Fulgham. 1989. Grazing systems and management of Mediterranean-type plant communities. In: Proceedings of the 16th International Grasslands Congress: Man and the Biosphere Symposium on Landscape Ecology; 8 October 1989; Nice, France. p 78-94.

Hanselka, C. W., A. McGinty, B. S. Rector, R. C. Rowan, and L. D. White. 1990. Grazing and brush management on Texas rangelands: an analysis of management decisions. College Station, TX: Texas Agricultural Extension Service Technical Report. $22 \mathrm{p}$.

Harris, T. R., A. Bhattacharyya, W. G. Kvasnicka, and G. M. Veserat. 1995. What type of rancher looks for new technology. Rangelands 17:217-221.

Heady, H. F. 1977. Valley grassland. In: M. G. Barbour and J. Major [eds.] Terrestrial vegetation of California. New York, NY: Wiley \& Sons. p 491-514.

Hickman, J. C. 1993. The Jepson manual: Higher plants of California. Berkeley, CA: University of California Press. 1424 p.

Hunt, E. R., JR., J. H. Everitt, J. C. Ritchie, M. S. Moran, D. T. Booth, G. L. Anderson, P. E. Clark, and M. S. Seyfried. 2003. Applications and research using remote sensing for rangeland management. Photogrammetric Engineering and Remote Sensing 69:675-693.

Jensen, M. N. 2001. Can cows and conservation mix? BioScience 51:85-90.
Kreuter, U. P., H. E. Amestoy, D. N. Ueckert, and W. A. McGinty. 2001. Adoption of brush busters: results of Texas county extension survey. Journal of Range Management 54:630-639.

Lass, L. W., H. W. Carson, and R. H. Callihan. 1996. Detection of yellow starthistle (Centaurea solstitialis) and common St. Johnswort (Hypericum perforatum) with multispectral digital imagery. Weed Technology 10: 466-474.

Lusk, W. C., M. B. Jones, D. T. ToRell, and C. M. McKell. 1961. Medusahead palatability. Journal of Range Management 14:248-251.

Maddox, D. M., and A. Mayfield. 1985. Yellow starthistle infestations are on the increase. California Agriculture 39:10-12.

Malmstrom, C. M., H. S. Butterfield, C. P. Barber, S. Bradenburg, C. C. Hughes, J. Qı, T. Robinson, A. Schrotenboer, C. Stoner, P. Varnakovida, and T. Yoshida. 2004. Using remote sensing to assess forage dynamics in a California rangeland restoration program. Final Report: Project 01-N31. Sacramento, CA: CALFED Ecosystem Restoration Program. $79 \mathrm{p}$.

Miles, M. B., and A. M. Huberman. 1994. Qualitative data analysis: An expanded sourcebook. 2nd ed. Thousand Oaks, CA: Sage Publications. 337 p.

Peters, A., D. E. Johnson, and M. R. George. 1996. Barb goatgrass: a threat to California's rangelands. Rangelands 18:8-10.

Pickup, G., G. N. Bastin, and V. H. Chewings. 1994. Remote-sensing-based condition assessment for nonequilibrium rangelands under large-scale commercial grazing. Ecological Applications 4:497-517.

QI, J., R. Marsett, and P. Hellman. 2000. Rangeland vegetation cover estimation from remotely sensed data. $I n$ : Proceedings of the 2nd International Conference on Geospatial Information in Agriculture and Forestry; 10-12 January 2000; Lake Buena Vista, FL. p 243-252.

Rogers, E. M. 1995. Diffusion of innovations. 4th ed. New York, NY: Free Press. $518 \mathrm{p}$.

RöLIng, N. G., ANd M. A. E. Wagemakers. 1998. Facilitating sustainable agriculture. Cambridge, UK: Cambridge University Press. 318 p.

Somers, N. 1998. Learning about sustainable agriculture: the case of Dutch arable farmers. In: N. G. Röling and M. A. E. Wagemakers [EDs.]. Facilitating sustainable agriculture. Cambridge, UK: Cambridge University Press. p 125-133.

Strauss, A., AND J. M. CoRBin. 1998. Basics of qualitative research: Techniques and procedures for developing grounded theory. 2nd ed. Thousand Oaks, CA: Sage Publications. $311 \mathrm{p}$.

Washington-Allen, R. A., N. E. West, R. D. Ramsey, and R. A. Efroymson. 2006. A protocol for retrospective remote sensing-based ecological monitoring of rangelands. Rangeland Ecology and Management 59:19-29.

WeISS, S. B. 1999. Cars, cows, and checkerspot butterflies: nitrogen deposition and management of nutrient-poor grasslands for a threatened species. Conservation Biology 13:1476-1486.

YIN, R. K. 2003. Case study research: Design and methods. 3rd ed. Thousand Oaks, CA: Sage Publications. $181 \mathrm{p}$

Young, J. A. 1992. Ecology and management of medusahead (Taeniatherum caput-medusae ssp. asperum [simk.] melderis). Great Basin Naturalist 52: 245-252. 